\title{
Agroindustrial byproducts in diets for Nile tilapia juveniles ${ }^{1}$
}

\author{
João Sérgio Oliveira Carvalho², Rafael Vieira de Azevedo², Ana Paula de Souza Ramos², \\ Luís Gustavo Tavares Braga ${ }^{2}$
}

\author{
${ }^{1}$ FAPESB, CNPq, CAPES e Pratigi Alimentos SA. \\ 2 Universidade Estadual de Santa Cruz, Laboratório de Nutrição e Alimentação de Peixes, Rod. Ilhéus-Itabuna, Km 16, 45662-900 - Ilhéus, BA.
}

\begin{abstract}
This study was conducted to evaluate performance and body composition of tilapia (Oreochromis niloticus) fed diets containing byproducts aerial parts of cassava meal (Manihot esculenta), mesquite pod meal (Prosopis juliflora), cocoa meal (Theobroma cacao) and palm kernel cake (Elaeis guineensis) and to analyze the economic viability of the feed. A total of 1,350 juvenile males (100 g) were distributed in 15 cages $\left(1 \mathrm{~m}^{3}\right)$ in completely randomized design with five treatments (basal diet and four test diets) and three replicates. The following aspects were evaluated: final weight, total feed intake, total weight gain, feed conversion, specific growth rate, protein efficiency ratio and survival rate, dry matter, crude protein, fat and ash body, the average cost of feed per kilogram of weight gain and economic efficiency rate. No differences were observed for total consumption of food or survival rate. For other variables, the inclusion of cocoa and cassava meal impaired fish performance. No differences were observed for dry matter, crude protein and body ash. The lower body fat accumulation was recorded for the tilapia fed palm kernel cake. The best economic indicators were found to diets containing palm kernel cake. The byproducts evaluated can be used up to $150 \mathrm{~g} / \mathrm{kg}$ in feed formulation, providing good performance and economic rate for Nile tilapia.
\end{abstract}

Key Words: economic evaluation, feed alternative, Oreochromis niloticus, productive performance

\section{Introduction}

Nile tilapia (Oreochromis niloticus) is one of the most commonly used species in intensive farms in Brazil, considered the most promising for fish farming due to the rapid growth in captivity and for having good quality meat (Furuya et al., 2008). It is omnivorous and takes diets with great ease, from the post-larva to the finishing phase (Boscolo et al., 2001).

The increase in productivity requires the use of complete diets, since the natural feed is not able to meet the requirements of fish, especially when raised in tanks and "raceways", where high biomass per unit area and nutrient deficiencies or imbalance can lead to productivity losses and consequently lower economic profit (Furuya et al., 2001). In intensive fish farming, the feeding factor can reach up to $70 \%$ of the total production cost (Guimarães et al., 2008), a fact that has stimulated studies on feeding of fish with the use of alternative foods that meet the nutritional requirements of animals, without, however, altering the quality of diet.

There is a wide variety of foods with potential for use in feeding of tropical fish. Thus, studies involving the use of agroindustrial byproducts as components of fish diet have become increasingly common (Mbahinzireki et al. 2001; Omoregie, 2001; Cheng \& Hardy, 2002; Santos et al., 2009; Lopes et al., 2010).

In this context, the objective of this research was to assess performance and body composition of tilapias (Oreochromis niloticus) fed diets containing the byproducts: aerial parts of cassava meal (Manihot esculenta), mesquite pods meal (Prosopis juliflora), cocoa meal (Theobroma cacao) and palm kernel cake (Elaeis guineensis).

\section{Material and Methods}

The experiment was conducted at Vale do Juliana Farm (Aquavale), in the city of Ituberá, Bahia, Brazil, located at geographic coordinates Latitude $13^{\circ} 53^{\prime} 45^{\prime \prime}$ and Longitude 39¹7' 10", for 60 days between January and March 2010.

A total of 1350 juvenile Nile tilapia (Oreochromis niloticus), Thai strain, sexually reverted to male and with an initial weight of $100.0 \pm 3.5$ g were used. A completely randomized design with five treatments and three replicates was used; each tank was considered an experimental unit.

The fish were distributed in 15 tanks $(1.0 \times 1.0 \times 1.2 \mathrm{~m}$, working volume of $1 \mathrm{~m}^{3}$ ), with a mesh of $17 \mathrm{~mm}$ between 
knots, with stocking density of 90 fish per $\mathrm{m}^{3}$. The average depth $(4.0 \pm 1.3 \mathrm{~m})$ was determined by bathymetry (Sonar). The tanks were arranged in a row ( $30 \mathrm{~m}$ ) with $2 \mathrm{~m}$ of spacing between tanks.

Treatments consisted of a control diet, free from byproduct, and four test diets, each one including a byproduct (cassava leaf meal, mesquite pod meal, cocoa meal and palm kernel cake), in proportion of $150 \mathrm{~g} / \mathrm{kg}$, considering the pre-tests performed regarding their palatability to the tilapia. In these studies, it was observed that values above $150 \mathrm{~g} / \mathrm{kg}$ of inclusion of the respective byproducts resulted in reduced consumption of the diets.

All diets were formulated according to the NRC recommendations (1993) and based on values of apparent digestibility coefficients of the byproducts (Braga et al., 2010) and other ingredients (Boscolo et al. 2002) for the Nile tilapia (Table 1).
To prepare the control diet and test diets (Table 2), all ingredients and byproducts were ground separately and sieved using a $0.7-\mathrm{mm}$ mesh sieve. Later, they were weighed according to each treatment, mixed, and again crushed using a $0.3-\mathrm{mm}$ sieve. Then, vitamin and mineral supplement, lysine, BHT and soybean oil were added, and the resulting mixture was taken to the extruder. Diets were processed using 4-mm diameter array, dried in a condenser, stored and identified according to the treatments. All manufacturing steps of diets were performed in the Food Plant of UNESP FCAV, Jaboticabal campus.

The fish were fed four times a day (8:00 a.m., 11:00 am, 2:00 pm and 4:00 pm), with supply of diet until their apparent satiation. Biweekly, samples were collected from fish for performance monitoring by means of samples from nine fish in each tank.

The physico-chemical variables of water, $\mathrm{pH}(6.8 \pm 0.1)$ and dissolved oxygen $(4.8 \pm 0.8 \mathrm{mg} / \mathrm{L})$ were monitored weekly

Table 1 - Chemical composition of byproducts used in experimental diets

\begin{tabular}{|c|c|c|c|c|}
\hline$\overline{\text { Variable }}$ & Cassava leaf meal & Mesquite pod meal & Cocoa meal & Palm kernel cake \\
\hline Dry matter $(\mathrm{g} / \mathrm{kg})$ & 927.4 & 903.4 & 918.3 & 930.8 \\
\hline Mineral matter $(\mathrm{g} / \mathrm{kg})$ & 65.0 & 62.5 & 61.3 & 11.5 \\
\hline Crude fiber (g/kg) & 245.0 & 40.0 & 260.0 & 569.0 \\
\hline Digestible protein $(\mathrm{g} / \mathrm{kg})^{1}$ & 80.4 & 145.3 & 37.3 & 120.8 \\
\hline Digestible energy $(\mathrm{kcal} / \mathrm{kg})^{1}$ & 1.246 & 5.81 & 9.26 & 2.731 \\
\hline
\end{tabular}

${ }^{1}$ Based on the values of apparent digestibility coefficients obtained by Braga et al., 2010.

Table 2 - Composition of experimental diets in $\mathrm{g} / \mathrm{kg}$ of natural material

\begin{tabular}{|c|c|c|c|c|c|}
\hline \multirow[t]{2}{*}{ Food (g/kg) } & \multicolumn{5}{|c|}{ Treatment } \\
\hline & Control & Сосоа & Mesquite & Palm & Cassava \\
\hline Fish meal & 280.0 & 290.0 & 280.0 & 270.0 & 267.8 \\
\hline Wheat meal & 120.0 & 120.0 & 120.0 & 107.4 & 120.0 \\
\hline Corn meal & 198.4 & 135.5 & 96.8 & 140.0 & 145.0 \\
\hline Cottonseed meal & 200.0 & 41.8 & 95.1 & 101.3 & 48.0 \\
\hline BHT antioxidant & 0.2 & 0.2 & 0.2 & 0.2 & 0.2 \\
\hline L-lysine $\mathrm{HCl}$ & 1.1 & - & - & 2.1 & - \\
\hline Cocoa meal & - & 150.0 & - & - & - \\
\hline Mesquite pod meal & - & - & 150.0 & - & - \\
\hline Palm kernel cake & - & - & - & 150.0 & - \\
\hline Cassava leaf meal & - & - & - & - & 150.0 \\
\hline Crude fiber (g/kg) & 78.6 & 80.0 & 63.1 & 80.0 & 80.0 \\
\hline Fat $(\mathrm{g} / \mathrm{kg})$ & 54.7 & 76.7 & 80.0 & 53.1 & 62.6 \\
\hline Lysine (g/kg) & 20.0 & 18.9 & 18.8 & 20.0 & 20.0 \\
\hline
\end{tabular}


and temperature (25.6 $\left.\pm 1.1^{\circ} \mathrm{C}\right)$ was monitored daily by morning and afternoon, using a multiparameter meter. The values remained within the recommended range for the farming of this species (Ross, 2000).

Chemical analyses of dry matter, mineral matter, crude protein, gross energy and crude fiber of byproducts were performed at the Laboratory of Animal Nutrition, Universidade Estadual de Santa Cruz (UESC), Ilhéus, BA, according to the techniques described by AOAC (2000).

At 60 days of experiment, the final biometrics of the fish was performed, resulting in the total weight in each experimental unit. Two copies of each treatment were randomly removed using dip nets; fish were sacrificed with an overdose of anesthetic benzocaine $(120 \mathrm{mg} / \mathrm{L})$, and then packed in plastic bags identified and kept in a freezer $\left(-10^{\circ} \mathrm{C}\right)$ for further body composition analysis. The same procedure was carried out at the beginning of the experiment with ten fishes, sampled at random.

For analysis of initial and final body composition of tilapias, they were crushed in an industrial blender and predried in a forced ventilation oven $\left(65^{\circ} \mathrm{C}\right)$ for 72 hours. Initially, quantitative analysis of fat content was performed to enable the grinding and mixing of samples. After this procedure, degreased samples were crushed in a knife mill (1-mm sieve) for posterior determination of dry matter, crude protein, ash and energy.

For the analysis of animal performance, final weight, total weight gain, total diet consumption, apparent feed conversion, protein efficiency rate, specific growth rate and survival rate were assessed.

To analyze the economic viability of diets containing byproducts, data were collected regarding the amount and price of inputs used in the suppliers of ingredients. The cost of diets used in this experiment was calculated based on retail prices; however, these values were converted into dollars.

The cost of diet per kg of weight gain was calculated according to Bellaver et al. (1985). After obtaining this value, the economic efficiency index was calculated according to Barbosa et al. (1992).

Data on animal performance and body composition of fish obtained at the end of the experiment were subjected to variance analysis as per totally randomized design $(\alpha=0.05)$. In case of differences between treatments, the Tukey test was applied. All procedures were performed using the PROC GLM of SAS (Statistical Analysis System, version 9.0).

\section{Results and Discussion}

There was no mortality case in any of the treatments, confirming that diets containing up to $150 \mathrm{~g} / \mathrm{kg}$ of byproducts can be used without any harm to fish. It is also noteworthy that the environmental conditions and animal management were adequate during the experimental period.

No significant differences for the variables total diet intake and survival rate were observed for the different byproducts tested in diets for Nile tilapia. For other variables, including the different byproducts, it significantly altered the fish performance (Table 3).

Tilapias showed different animal performance for the variable final weight and total weight gain, as well as for specific growth rate. Fishes ingesting diets with cocoa meal and cassava foliage meal had, respectively, final weight $13.2 \%$ and $8.5 \%$ lower than for those in the control diet. These results directly reflected on the total weight gain, and this parameter for control diet is 17.8 and $11.4 \%$ higher than that found in diets with cocoa and cassava foliage, respectively. The specific growth rate followed the same trend, confirming itself through the worst results in tilapias that consumed the same byproducts.

The apparent food conversion and protein efficiency rate of fishes ingesting diets containing cocoa meal worsened in 16.7 and $15.5 \%$, respectively, when compared with fishes ingesting the control diet. However, they showed similar values to those of other treatments.

Table 3 - Performance of tilapia fed with basal diet and diets with byproducts

\begin{tabular}{|c|c|c|c|c|c|c|c|}
\hline \multirow[t]{2}{*}{ Variable } & \multicolumn{5}{|c|}{ Treatment } & \multirow[t]{2}{*}{ P Value } & \multirow[t]{2}{*}{ CV (\%) } \\
\hline & Control & Cocoa & Palm & Mesquite & Cassava & & \\
\hline Initial weight (g) & $100 \pm 3.5$ & $100 \pm 3.5$ & $100 \pm 3.5$ & $100 \pm 3.5$ & $100 \pm 3.5$ & - & - \\
\hline Total diet intake (kg) & 29.79 & 28.66 & 28.26 & 30.87 & 29.84 & 0.067 & 3.5 \\
\hline Total weight gain $(\mathrm{kg})$ & $26.13 \mathrm{a}$ & $21.49 b$ & 23.93ab & 23.93ab & $23.14 b$ & 0.003 & 4.2 \\
\hline Apparent food conversion & $1.14 \mathrm{~b}$ & $1.33 \mathrm{a}$ & $1.18 \mathrm{ab}$ & $1.29 \mathrm{ab}$ & $1.29 \mathrm{ab}$ & 0.023 & 5.3 \\
\hline Survival rate (\%) & 100.00 & 100.00 & 100.00 & 100.00 & 100.00 & - & - \\
\hline
\end{tabular}

Means in rows, followed by different letters, differ statistically by Tukey test $(\mathrm{P}<0.05)$; CV - coefficient of variation. 
Oliveira et al. (1997) found no differences in values of weight gain of Nile tilapia when under diets containing up to $350 \mathrm{~g} / \mathrm{kg}$ of palm kernel cake. In an experiment with cocoa husk meal for Nile tilapia, Falaye \& Jauncey (1999) had values up to $74 \%$ higher than those found in this experiment for weight gain, which can be explained by the different stages of development of fish and the different amounts of protein used in the experiments. However, the results obtained for weight gain for all byproducts used in this experiment are similar to those obtained by Boscolo et al. (2001) using commercial diet $(280 \mathrm{~g} / \mathrm{kg}$ crude protein) for Nile tilapia, Thai strain, mean initial weight of $60.73 \mathrm{~g}$.

The lowest values for weight gain obtained by fishes fed cocoa meal may be due to the presence of antinutritional factors, such as theobromine (Bonvehí \& Coll, 2000). It should also be noted that the difference of $10 \mathrm{~g} / \mathrm{kg}$ of digestible protein and $100 \mathrm{kcal} / \mathrm{kg}$ of digestible energy in diets with cocoa meal and cassava foliage, when compared with the diet containing palm oil, may have affected the tilapia growth.

Regarding the specific growth rate (\%/day) for fish ingesting diets containing palm kernel cake, values similar to those obtained in this experiment were obtained by Oliveira et al. (1997) in a research with Nile tilapia, when they found specific growth rate ranging from 1.98 to 2.02. Dealing with cocoa meal to Nile tilapia, Falaye \& Jauncey (1999) obtained values for specific growth rate ranging from 3.3 to 3.5 according to the level of inclusion of the byproduct, higher than those obtained in this experiment, which may be due to the size of fishes $(0.97 \pm 0.02 \mathrm{~g})$ used by these authors.

Falaye \& Jauncey (1999) investigated the effects of addition of cocoa meal to Nile tilapia and had the worst food conversion values obtained in the present experiment, ranging from 4.3 to 4.9. Similarly, Oliveira et al. (1997), in a research of palm kernel cake for the same species, observed values of apparent feed conversion ranging from 2.01 to 2.18 , according to the level of inclusion of the byproduct. Even though fish raised in tanks have restricted access to natural feed (Ono \& Kubitza, 2003), its availability may have been responsible for the differences obtained, since these experiments were conducted in laboratories, in enclosed systems with recirculating water. It should be emphasized that extruded diets (used in this experiment) tend to have higher digestibility than pelleted diets, which may be responsible for better apparent feed conversion. The results for this variable for all byproducts assessed are within the commonly observed range for the intensive farming of tilapias (Kubitza, 2000).

Oliveira et al. (1997) and Falaye \& Jauncey (1999) found lower values than those obtained in this experiment for protein efficiency ratio in Nile tilapia. Working with palm kernel cake, the first authors found values ranging from 1.54 to $1.67 \%$, according to the level of inclusion of byproduct. In the second study, using cocoa meal, the authors found values of protein efficiency ratio of 0.67 and $0.74 \%$, respectively, for the inclusion levels of 100 and $200 \mathrm{~g} / \mathrm{kg}$ of byproduct. The various processing of diets may have influenced protein digestibility. In addition, the diets used in this experiment were based on digestible protein rather than crude protein, which may have been responsible for the better utilization of this nutrient, as observed by other authors (Pezzato et al., 2009; Boscolo et al., 2010).

For the variables dry matter, crude protein and body mineral matter of tilapias fed different experimental diets, no significant differences were seen (Table 4).

In relation to body fat, fishes fed palm kernel cake and cassava foliage meal had the lowest rates, differing significantly from fishes fed cocoa meal and similar to those under control diet and diets containing mesquite pod meal. Oliveira et al. (1997) found mean values of 980.2, 543.6 and $128.1 \mathrm{~g} / \mathrm{kg}$, respectively, for dry matter, crude protein and body mineral matter of Nile tilapia subjected to diets with different levels of inclusion of palm kernel cake.

According to Veiverberg et al. (2010), variable results on body composition of fishes are obtained as the effect of inclusion of plant ingredients, with the main response observed in the body fat and/or fillet contents. In addition to the energy/protein, a diet with an imbalanced amino acid profile can result in greater fat deposition (Botaro et al., 2007), which may explain the variation in this experiment of

Table 4 - Body composition of Nile tilapia fed with basal diet and diets with byproducts

\begin{tabular}{|c|c|c|c|c|c|c|c|}
\hline \multirow[t]{2}{*}{ Variable } & \multicolumn{5}{|c|}{ Treatment } & \multirow[t]{2}{*}{ P Value } & \multirow[t]{2}{*}{ CV (\%) } \\
\hline & Control & Cocoa & Palm & Mesquite & Cassava & & \\
\hline Dry matter (g/kg) & 254.6 & 255.9 & 243.5 & 259.2 & 254.1 & 0.314 & 3.5 \\
\hline Crude protein ${ }^{1}$ (g/kg) & 738.4 & 754.1 & 757.1 & 737.4 & 757.6 & 0.331 & 1.2 \\
\hline Fat $^{1} \quad(g / k g)$ & 573.6ab & $606.1 \mathrm{a}$ & $536.1 \mathrm{~b}$ & $571.6 \mathrm{ab}$ & $537.8 b$ & 0.004 & 3.9 \\
\hline Mineral matter (g/kg) & 144.8 & 142.6 & 183.5 & 148.3 & 136.7 & 0.082 & 3.1 \\
\hline
\end{tabular}

Means in rows, followed by different letters, differ statistically by Tukey test $(\mathrm{P}<0.05)$; CV - coefficient of variation.

${ }^{1}$ Values expressed in $\mathrm{g} / \mathrm{kg}$ of dry matter. 
fat values in the carcass. In this sense, the high biological value of palm oil protein had already been pointed out by Jauncey \& Ross (1982).

The mean measurement of body crude protein was $749 \mathrm{~g} / \mathrm{kg}$, with low coefficient of variation, showing the stability of this variable in body composition. This confirms the observations made by Cho et al. (1976) that there is a direct relationship between body composition and composition of the diet that the animals are ingesting.

There was a variation of U\$ 0.06 (cents) between the diets of higher (mesquite) and lower cost (palm) (Table 5).

Regarding the cost of diet per kg of weight gain, we can see that the diet consisting of palm kernel cake, plus the control diet, tended to provide better rates when compared with diets containing cocoa meal, mesquite pod and cassava foliage, which can be explained by the small difference in cost per $\mathrm{kg}$ of diet, which made the economic analysis dependent on animal performance indexes. The diet with the highest index of economic efficiency was that including palm kernel cake.

A common difficulty observed when alternative feed sources are used in fish feed is acceptability, which is related to palatability (Rodriguez et al., 1996). In this research, there was wide acceptance to all diets, showed by the lack of significance for the variable total feed intake, demonstrating that the level of inclusion $(150 \mathrm{~g} / \mathrm{kg})$ of byproducts and the addition of high palatability of ingredients, such as fish flour, were effective.

Table 5 - Average cost per kg of diet, cost of diet per kg of weight gain, and economic efficiency index of cultivation of Nile tilapia fed with experimental diets ${ }^{1}$

\begin{tabular}{|c|c|c|c|c|c|}
\hline \multirow[t]{2}{*}{ Variable } & \multicolumn{5}{|c|}{ Treatment } \\
\hline & Control & Cocoa & Palm & Mesquite & Cassava \\
\hline $\mathrm{U} \$ / \mathrm{kg}$ & 0.63 & 0.62 & 0.60 & 0.66 & 0.65 \\
\hline U\$/weight gain & 0.73 & 0.83 & 0.71 & 0.85 & 0.83 \\
\hline Index of economic efficiency (\%) & 97.82 & 85.98 & 100.00 & 83.34 & 84.99 \\
\hline
\end{tabular}

${ }^{1}$ Exchange rate of the dollar at the time: $\mathrm{R} \$ 1.72$.

\section{Conclusions}

The mesquite meal and palm kernel cake promote better growth of Nile tilapia when compared with cocoa meal and cassava leaf meal. The best economic efficiency index is achieved with the use of palm kernel cake.

\section{Acknowledgments}

The authors would like to thank FAPESB, for granting the graduate student fellowship; CNPq, CAPES and Pratigi Alimentos SA, for funding the research project; Aguavale Farm, which made the experiment possible and Vitaly Foods, Riocon, Coopatan, Opalma and Cargill, for providing the byproducts.

\section{References}

ASSOCIATION OF OFFICIAL ANALYTICAL CHEMISTS - AOAC. Official methods of analysis of AOAC International. 17.ed. Washington, D.C., 2000. 1018p.

BARBOSA, H.P.; FIALHO, E.T.; FERREIRA, A.S. Triguilho para suínos nas fases de crescimento, crescimento e terminação. Revista Brasileira de Zootecnia, v.21, p.827-837, 1992.

BELLAVER, C.; FIALHO, E.T.; PROTAS, J.F.S. Radícula de malte na alimentação de suínos em crescimento e terminação. Pesquisa Agropecuária Brasileira, v.20, p.969-974, 1985.
BONVEHÍ, J.S.; COLL, F.V. Evaluation of purine alkaloids and diketopiperazines contents in processed cocoa powder. European Journal of Food Research Technology, v.210, p.189-195, 2000.

BOSCOLO, R.W.; HAYASHI, C.; SOARES, C.M. et al. Desempenho e características de carcaça de machos revertidos de tilápias do Nilo (Oreochromis niloticus), linhagem tailandesa e comum, na fase inicial e de crescimento. Revista Brasileira de Zootecnia, v.30, p.1391-1396, 2001.

BOSCOLO, W.R.; HAYASHI, C.; MEURER, F. Digestibilidade aparente da energia e nutrientes de alimentos convencionais e alternativos para a tilápia do Nilo (Oreochromis niloticus, L.). Revista Brasileira de Zootecnia, v.31, p.539-545, 2002.

BOSCOLO, W.R.; HAYASHI, C.; FEIDEN, A. et al. Inclusão de milheto em dietas para alevinos de tilápia-do-nilo formuladas com base na proteína e energia digestíveis. Revista Brasileira de Zootecnia, v.39, p.950-954, 2010.

BOTARO, D.; FURUYA, W.M.; SILVA, L.C.R. et al. Redução de proteína da dieta com base no conceito de proteína ideal para tilápias-do-nilo (Oreochromis niloticus) criadas em tanques-rede. Revista Brasileira de Zootecnia, v.36, p.517-525, 2007.

BRAGA, L.G.T.; RODRIGUES, F.L.; AZEVEDO, R.V. et al, Digestibilidade aparente da energia e nutrientes de coprodutos agroindustriais para tilápia do Nilo. Revista Brasileira de Saúde e Produção Animal, v.11, p.1127-1136, 2010.

CHENG, Z.J.; HARDY, R.W. Effect of microbial phytase on apparent nutrient digestibility of barley, canola meal, wheat and wheat middlings, measured in vivo using rainbow trout (Oncorhynchus mykiss). Aquaculture Nutrition, v.8, p.271-277, 2002.

CHO, C.Y.; SLINGER, J.; BAILER, H.S. Influence of level and type of dietary protein, and of level of feeding on feed utilization by rainbow trout. Journal of Nutrition, v.106, p.1547-1556, 1976. 
FALAYE, A.E.; JAUNCEY, K. Acceptability and digestibility by tilapia Oreochromis niloticus of feeds containing cocoa husk. Aquaculture Nutrition, v.5, p.157-161, 1999.

FURUYA, W.M.; FUJII, K.M.; SANTOS, L.D. et al. Exigência de fósforo disponível para juvenis de tilápia-do-nilo. Revista Brasileira de Zootecnia, v.37, p.1517-1522, 2008.

FURUYA, W.M.; PEZZATO, L.E.; PEZZATO, A.C. et al. Coeficientes de digestibilidade e valores de aminoácidos digestíveis de alguns ingredientes para tilápia do Nilo (Oreochromis niloticus). Revista Brasileira de Zootecnia, v.30, p.1143-1149, 2001.

GUIMARÃES, I.G.; MIRANDA, E.C.; RIBEIRO, V.L. et al. Farinha de camarão em dietas para tilápia do Nilo (Oreochromis niloticus). Revista Brasileira de Saúde e Produção Animal, v.9, p.140-149, 2008.

JAUNCEY, K.; ROSS, B. A guide to tilapia feeds and feeding. Stirling: Institute of Aquaculture University of Stirling, 1982. 111p.

KUBITZA, F. Tilápia: tecnologia e planejamento na produção comercial. Jundiaí: F. Kubitza, 2000. 285p.

LOPES, J.M.; PASCOAL, L.A.F.; SILVA FILHO, F.P. et al. Farelo de babaçu em dietas para tambaqui. Revista Brasileira de Saúde e Produção Animal, v.11, p.519-526, 2010.

MBAHINZIREKI, G.B.; DABRIWSKI, K.; LEE, K.J. et al. Growth, feed utilization and body composition of tilapia (Oreochromis sp.) fed with cottonseed meal-based diets in a recirculating system. Aquaculture Nutrition, v.7, n.3, p.189-200, 2001.

NATIONAL RESEARCH COUNCIL - NRC. Nutrient requirements of warm water, fishes and shellfishes: nutrient requirements of domestic animals. Washington, D.C.: National Academic Press, 1993. 114p.
OLIVEIRA, A.C.B.; PEZZATO, L.E.; BARROS, M.M. et al. Torta de dendê em dietas para a tilápia do Nilo: desempenho produtivo. Pesquisa Agropecuária Brasileira, v.32, p.443-449, 1997.

OMOREGIE, E. Utilization and nutrient digestibility of mango seeds and palm kernel meal by juvenile Labeo senegalensis (Antheriniformes: Ciprinidae). Aquaculture Research, v.32, p.681-687, 2001.

ONO, E.A.; KUBITZA, F. Cultivo de peixes em tanques-rede. 3.ed. revisada e ampliada. Jundiaí, 2003. 111p.

PEZZATO, L.E.; BARROS, M.M.; FURUYA, W.M. Valor nutritivo dos alimentos utilizados na formulação de rações para peixes tropicais. Revista Brasileira de Zootecnia, v.38, p.43-51, 2009 (supl. especial).

RODRIGUEZ, S.M.; OLVERA, N.M.A.; CARMONA, O.C. Nutritional value of animal byproduct meal in practical diets for Nile tilapia, Oreochromis niloticus (L.) fry. Aquaculture Research, v.27, p.67-73, 1996.

ROSS, L.G. Environmental physiology and energetics. In: BEVERIDGE, M.C.M.; MCANDREW, B.J. (Eds.) Tilapias: biology and exploitation. Dordrecht: Kluwer Academic Publishers, 2000. p.89-128.

SANTOS, E.L.; LUDKE, M.C.M.M.; BARBOSA, J.M. et al. Níveis de farelo de coco em rações para alevinos de tilápia do Nilo. Revista Brasileira de Saúde e Produção Animal, v.10, p.390-397, 2009.

VEIVERBERG, C.A.; RADÜNZ-NETO, J.; SILVA, L.P. et al. Teores de proteína bruta em dietas práticas para juvenis de carpa capim. Arquivo Brasileiro de Medicina Veterinária e Zootecnia, v.62, p.1241-1249, 2010. 